Lunacy Legislation in Nero Zealand. By W. LAUDER LINDsaT, M.D., F.R.S.E., Physician to the Murray Royal Institution (for the Insane), Perth.

Some months ago, in an article on "Colonial Lunacy Boards," [in the number of the "Edinburgh Medical Journal" for March, 1872,] I had occasion to announce that the New Zealand Government had put upon paper certain "Resolutions"1 regarding Lunacy-Reform in the Colony, including a proposal forthwith to appoint at least one Commissioner in Lunacy, who should act as adviser to Government in all Lunacy matters, as well as supervise all the Lunatic Asylums of the Colony. I expressed a fear that the intentions apparently embodied in the said resolutions were " too good news to be true," and that they would prove but formal suggestions-to be laid upon the table of the House of Assembly, there to remain [shelved] for an indefinite period, just as similar proposals for Lunacy Reform have been treated in the sister colony of New South Wales. Unfortunately for the insane, and for the Lunatic Hospitals, of New Zealand, my surmises have proved to be only too correct -my fears only too well founded. By the Angust mail (1872) I received two letters from the Honourable Dr. Buchanan, of Dunedin, Member of the Legislative Council, and mover of the Parliamentary Resolutions above referred to. ${ }^{2}$ That the proposals which these resolutions contained, have not yet been adopted, is certainly no fault of his; for of his hearty interest and honest intention in the matter there can be no question. In his letters he gives the following most unsatisfactory account of the present state of affairs in New Zealand in regard to Lunacy Progress or Reform-a

1 They are prefixed to a "Report of the Joint Committee upon Lunatio Asylums," seid Committee consisting of 15 members of both Houses of Assembly; printed by order of the Legislative Council in October, 1871 ; for a copy whereof I am indebted to the courtesy of the Honble. Dr. Buchanan, chairman of the Committee.

- I received, also, by the same mail-owing to the kind attention of my friend, John Hislop, Esq., Inspector of Schools for the Province of Otago-a copy of the "Parliamentary Debates" of 1871 (No. 5, dated September 18th), containing the discussion of September 7th, on the "Colonial Lunatic Asylum." And subsequently "Reports on Lunatic Asylums in New Zealand, presented to both Houses of the General Assembly, by command of His Excellency," in 1871, have come to hand. 
state of affairs which I quite agree with him in considering discreditable and disgraceful to its reputation as a British Colony!

"You are quite right," says he, in remarking that "the intention of the Governor-then Sir George Grey-was obviously more liberal 25 years ago than is that of the Government of the present day, inasmuch as he contemplated, even in the infancy of the Colony, the possibility, at least, of requiring more than one Visitor of the Colonial Lunatic Asylums.' But you are mistaken if you suppose that the present Government here is at all desirous, or has any intention whatever, of endeavouring to secure the services of even one duly qualified medical officer to supervise all our asylums! Whilst the Colony is spending some $£ 40,000$ a-year in postal subsidies, and several millions on public works and immigration, I am ashamed, as a colonist, to say that the Government refused a paltry $£ 1200$ or $£ 1500$ to provide for the medical officer recommended in the 3rd resolution ${ }^{8}$ of the Report of the Joint Committee of both Houses last Session-although the Report was passed unanimously; and although frightful cases of cruelty and ignorance were brought to light in the evidence taken by the Committee in one, at least, of these Institutions" [Lunatic Asylums].

"By dint of a great deal of pressure brought to bear on the provincial authorities, by exposing these abuses, this much only was gained at the end of the meeting of our Parliament-that a sum of $\$ 5000^{4}$ was voted to build a new asylum, on a new and better site, at Wellington, instead of 'the miserable, small, wooden hovel' (as Major Blewitt correctly described it to you) at Karori. Karori has been for many years 'the skeleton in the closet' of Wellington; and all concerned seem to have endeavoured to keep the door of it closed! It is only within a few weeks, and after the close of the Session of the Assembly, that, some of the servants of the Institution having quarrelled, the Government appointed a Commission of Inquiry ; when facts came to light as to the cruel treatment of some of the patients by the

- To wit : "That a duly qualified medical officer from the United Kingdom, having special knowledge and experience in the treatment of the insane, be forthwith engaged and appointed, and who shall have the supervision and control of all the Lunatic Asylums in the Colony."

- The paltriness of this sum, for the construction of a model asylum in the parliamentary capital of New Zealand, may be judged of by the fact that the new asylum for the Province of Auckland, erected in 1865 at the Whav, near the city of Auckland, cost upwards of $\$ 18,000$. 
keeper and his wife-who had had charge of the asylum for 13 years - which resulted in their dismissal. These facts will strengthen my hand in the course $I$ intend to continue to take, with the view of having one Inspector at least appointed for the Colony, entrusted with large powers. Had such an officer had the necessary control sooner, such scandals, which are a blot on our humanity, could scarcely have occurred."

" Unfortunately, I fear, there are not half-a-dozen members of the Assembly who have it earnestly at heart to get these abuses remedied; hence the apathy of the Government. We are willing enough to 'go in' for reproductive Public Works. But, of course, the care of the Insane costs money, and does not 'pay.' I fear that, before anything like justice can be done to these unfortunate creatures, who cannot speak for themselves, public opinion will have to be appealed to through the press. This I reserve as a dernier resort.

"To show the little interest taken in this matter by our public men, I may mention that the Joint Committee appointed last session by the Assembly consisted of fifteen members. At one of our meetings it was agreed that the committee should visit Karori in a body. But when the day and hour arrived, the only member who kept the appointment was myself, and I alone made the visit!'

Very properly, under these circumstances, does Dr. Buchanan announce his intention of "continuing to press on the Colonial Government, during the coming session of the General Assembly, the absolute necessity of doing something to improve the management of our Asylums for the Insane." Alluding to books treating of the proper management of the Insane, and of the construction and organisation, on modern principles, of Lunatic Asylums-as desirable additions ta the library of the House of Assembly, he adds"We have no works of the kind in that Institution, although there is no topic on which both the general public and also ' honourable members' more need enlightening."

In a letter published in the "Otago Daily Times," of June 27th, 1872, Dr. Buchanan thus further expresses himself on the same subject-pointing out to begin with that "what is merely the recommendation of a committee," I mistake "for a decision of the Executive"-[quoad the appointment of a Lunacy Commissioner]. "Unhappily this is not the case. On the contrary, during the late Session, the Government persistently declined to consider the proposition. In spite of the evidence and other documents attached to the report, the 
recommendations of which are most moderate and practical, ministers have hitherto, as far as I am aware, taken no steps whatever to give effect to the wishes of the committee by securing the services of a properly educated medical man as Inspector-General of our Asylums. It is quite clear that, in times past, in the absence of such an official, abuses and cruelty have occurred. Such an officer would encourage and strengthen the hands of those who so ably and zealously carry on the management of some of our Institutions" (for the insane); "while, on the other hand, he would detect, and expose, and reform mal-administration in others. . . . . . On looking again over this report, I find some of the evidence so painful and disgusting that I confess I have not the courage to quote it. Besides, I hope that, after the disclosures which have been made before the commission appointed at Wellington, during the recess, to enquire into certain charges of cruelty at Karori, the Government will by this time have seen fit to reconsider their decision as regards this question. . . . We have the laudable ambition of desiring to hold a front rank among British Colonies . . . . . Yet we refuse to devote a pitiful $£ 1000$ or $£ 1500$ to help our unfortunate fellowcreatures, who are too weak to make their wants and their sufferings known. . . . . . How shall we be regarded" (at home) "when the whole truth shall have been made known? ...... We shall be looked at with pity and contempt by the whole civilised world, even although all our enterprises for securing material prosperity should succeed beyond our most sanguine expectations!"

Sad, however, as is the apathy exhibited-in the foregoing picture-by the New Zealand Government and Public, as to the treatment of the insane, it would be an act of injustice to that Colony to let it be supposed that such a state of affairs is peculiar to it. So far from this being the case-though the statement of such a fact ought to furnish but a sorry kind of comfort or consolation to the New Zealand colonists-it must be confesssed that a similar condition of matters either has at one time existed, or does now exist, not only in all the British Colonies, but in Britain itself, and, indeed, in every country in the world, however civilised and reputedly humane and generous its. inhabitants. The treatment of the insane-either by commission or by omission-by deliberate cruelty, or by apathetic neglect-has, in certain states of society and stages of civilisation, in all parts "of the world, furnished only one illustration of "man's 
inhumanity to man." Colonial Legislators in particular -in the early years of the growth of newly settled communities, when what are called reproductive, and what are really purely selfish, though not the less necessary, works, absorb all the attention of the Law-makers-are too apt to be actuated by what may be termed the Prussic Acid Policy. They regard the insane as a public nuisance, and not only think, but sometimes do not hesitate to saythat the best means of dealing with them would be to rid society of their burden by poisoning them at once with prussic acid! ${ }^{5}$

In the neighbouring Colony of New South Wales repeated rumours have found their way into the public mind, through the Sydney newspapers, affecting the reputation of the large State Asylum at Tarban Creek (now known as Gladesville) near Sydney. A resultant Government Investigation took place so long ago as 1855-and since that date-in other words for a long series of years-there has existed among the public of the Colony in question, and especially of the City of Sydney, a feeling of suspicion and dissatisfaction; while Government is obviously even yet reluctant to grant the outlay necessary for reorganisation, on a proper scale and basis, of the chief Lunatic Hospital of the Colony ; for we learn from the last Report that has come to hand of the Hospital for the Insane at Gladesville [for the year 1870] that Dr. Manning, its physician, and the other authorities of that Institution and of the Lunatic Asylum at Paramatta, are still unsuccessfully pressing on the attention of an apathetic and parsimonious Government the necessity of reforming the arrangements for the management of the Colonial Insane. ${ }^{6}$ Public apathy and Government parsimony, in connection with the treatment of the insane, are more conspicuous in New South Wales than in New Zealand, simply on account of, and in proportion to, the greater size of its existing State Asylums, the much greater age of the Colony, and the substantial appearances of

- Vide the author's "Suggestions for the proper Supervision of the Insane, and of Lunatic Asylums, in the British Colonies." "British and Foreign Medico-Chirurgical Review," Oct. 1869, p. 493. Foot Note. This, however, is no worse, if no better, than the policy, favoured by the white settlers of certain of the American States, of Btrychnining their troublesome neighbours - the Red Indians !

- Vide Appendix B of said Report (p. 27) which consists of Memorands on " the accommodation for the Insane in the Colony of New South Wales, submitted to the Honourable the Colonial Secretary on July 23rd, 1870, by a Deputation consisting of the Visitors and Medical Officars of Asylums." 
a high state of civilisation in its capital city, Sydney.7 The New Zealand Legialator, who, in order to the organisation, on a sound basis and a proper scale, of a Colonial Lunacy system, is studying the procedure of other countries, probably will not find such a remarkable series of illustrations of the evils and absurdities of Government red-tapeism as are contained in the voluminous "Minutes of Evidence," on which was founded the report of the Sydney Commission of Inquiry of 1855. That report, by Commissioners appointed by the Government itself, contained a number of excellent suggestions; which, however, have not as yet been acted on. A new series of rumours8 only gave rise to another " report," (this time by Dr. Manning,) in $1868 ;^{\circ}$ but, though that gentleman has superseded the veteran Dr. Campbell in the management of Gladesville, Government has not apparently furnished him with the means, or the authority, to carry out the reforms that have so long been obviously required. One would think it unnecessary to criticise the state of matters in New South Wales, revealed by the "Minutes of Evidence" above mentioned; because the evils complained of are apparently fully recognised both by Government and Colonists, and the necessity for their reform unanimously admitted. But the singular fact remains that no adequate action has been taken for a quarter of a century. Nor is there even yet any immediate prospect of the execution of the much needed reforms.10 Instead, however, of taking comfort from so discreditable a state of matters in her sister Colony, instead of imitating the evil example of her elders or neighbours, it should be the aim of New Zealand to do, and that promptly, what is shown by competent authority or evidence to be right for the proper treatment of her Insane.

- New South Wales was colonised in 1788; while it was 1840 before Auckland, and 1848 before Otago, New Zealand, were settled.

- In 1863 the Rev. Dr. Willson, Roman Catholic Bishop of Hobartown, Tasmania, addressed a letter to the Colonial Becretary of New South Wales, pointing out the gross defects of the Tarban Creek Asylum, and making suggestions for the construction and organisation of a new State Asylum.

"Report on Lunatic Asylums," by Fred.N. Manning, M.D.: Sydney, 1868.

20 A state of things similar to what still exists in some perts at least of New Zealand, and to what has existed, if it does not still exist, in New South Wales, occurred in the Province of Victoria, Australia, as regards its State Asylum at Yarra Bend, and its Gaols, prior to 1862, when a Government Investigation took place, and was in due time followed by the desirable Reforms. (Vide article by Dr. Keene, in the "Australasian Medical and Surgical
Beview," for October, 1868.) 
In order that I may assist in pointing out what is, in present circumstances, right or proper for the New Zealand Government to do-that I may contribute to strengthen the position of the few Legislators, who, with Dr. Buchanan, may be disposed to press for proper attention, on the part of the Colonial Government, to the provision necessary for the humane treatment of all classes of the Colonial Insane-I venture to offer some remarks; (1) on the present state of Lunacy Legislation-of the Laws affecting Insanity and the Insane-in New Zealand; and (2) on the Reforms-additions or modifications - that appear necessary or desirable to adapt them to the requirements of the Colony in the present stage of its progress."

At the time of my own visit to New Zealand in 1861-2, the Lunacy Acts in operation were the two following, known respectively as the "Lunatics' Ordinance" of 1846, and the " Lunatics' Ordinance Amendment Act" of 1858. I quote them here ad longum ${ }^{12}$-(1) As a necessary basis for criticism or remark: (2) Because they are short and simple compared with the Lunacy Statutes of Scotland, England, or Ireland: (3) While they afford fair illustrations of British Colonial Lunacy Laws at an early stage in the history of the colonisation of a new country.

I.-Lunatics' Ordinance. Passed the 18th day of November, 1846, in the Tenth Year of the Reign of Her Majesty Queen Victoria. Session VII. No. XXI.

"Title.

"Analysis.

" Preamble.

“1.-Dangerous Lunatics may be apprehended and kept in custody,

"2.-But may have access to their friends,

" 3.-And may be placed in a Lunatic Asylum,

"4.-Until they shall recover.

"5.-Persons in Prison and being insane may be removed to an Asylum.

" 6.-Persons acquitted on ground of Insanity may be kept in custody.

" 7.-Persons proved not to be insane to be liberated.

"The reader may also consult the Paper (already quoted) in the "British and Foreign Medioo-Chirargical Review" for October, 1869.

12 The copy of the Act of 1846 I owe to the kindness of Jas. H. Crawford, Esq., Solicitor, Anckland, New Zealand, who wrote it out for me in April, 1862; while the Statute of 1858 was one of a series of printed Government docaments with which I was favoured in February, 1862, by His Honour, John Williamson, Superintendent of the Province of Auckland. 
“ 8.-Visitors of Lunatic Asylums may be appointed.

"9.-Persons insane, bat not dangerously so, may be placed in a Lunatic Asylum.

"10.-Costs of Maintenance to be defrayed by the Colony.

"11.-Relations, \&c., of Lunatic may pay such costs out of his Estate.

"12.-Limitation of Actions.

"13.-Who are to be deemed Legally-qualified Medical Practitioners.

"14.-Writ of de lunatico inquirendo may be issued in certain cases.

"15. - Interpretation.

"An Ordinance to make provision for the safe custody of, and prevention of Offences by, Persons dangerously insane; and for the care and maintenance of Persons of Unsound Mind.

"Whereas, it is expedient to make provision for the safe custody of, and prevention of crime being committed by, persons insane : Be it, therefore, enacted by the Lieutenant Governor of New Zealand, with the advice and consent of the Legislative Council thereof, as follows :-

"1.-If any person shall be discovered and apprehended under circumstances denoting a derangement of the Mind, and a purpose of committing suicide, or any crime for which, if committed, such person would be liable to be indicted, it shall be lawful for any two Justices of the Peace before whom such person may be brought, to call to their assistance any two legally-qualified Medical Praotitioners; and if upon view and examination of such person, and upon proof on oath by the said Medical Practitioners to the effect that, in their opinion, such person is a dangerous Lunatic or a dangerous Idiot, then it shall be lawful for the said Justices, by warrant, under their hands and seals, to commit such person to some Gaol, House of Correction, or Public Hospital, there to be kept in strict custody until such person shall be discharged by an order of two Justices of the Peace, one wherenf shall be one of the Justices who has signed such warrant, or by one of the Judges of the Supreme Court, or until such person shall be removed to some Public Colonial Lunatic Asylum by order of His Excellency the Governor, as hereinafter provided.

" 2.-Every such person, while in such custody as aforesaid, shall have the liberty of seeing his or her friends and legal advisers at all reasonable times; and nothing herein contained shall prevent any relative or friend from taking such Insane person or dangerous Idiot under his own care and protection, provided he enters into sufficient recognizance for the peaceable behaviour or safe custody of such dangerous Lunatic or Idiot before two Justices of the Peace, the Court of Sessions, or before one of the Judges of the Supreme Court.

" 3.-It shall be lawful for the Governor, by warrant, under. his 
hand, to direct that any person so kept in custody by any such warrant as aforesaid, or any Person who may be in any Prison or any place of confinement, except for debt or under any Civil Process, and in respect of whom it shall be certified by two legally-qualified Medical Practitioners that such person is insane, shall be removed to such Public Colonial Lunatic Asylum as the said Governor shall appoint.

"4.-Every person so removed as aforessid shall remain under confinement in the Asylum to which he may have been removed until it shall be certified to the Governor by two such Practitioners as aforesaid that such person has become of sound mind : whereupon the said Governor is hereby authorised and required, if such person shall remain snbject to be continued in custody, to issue his warrant to the keeper or other person having the care of any such Asylum, directing that such person be remitted to the Prison or other place of confinement from which he may have been taken, or if the period of imprisonment or custody of such person shall have expired, or if such person shall not be under any sentence of imprisonment, that such person shall be discharged : provided always that nothing herein contained shall prevent the relatives, guardians, or friends of any insane person or idiot from removing such person, with the sanction of His Excellency the Governor, from any Public Colonial Lunatic Asylum upon their giving sufficient security for the safe custody of such insane person or idiot in manner hereinbefore mentioned.

"5.-In case it shall be certified to the Governor by two such Practitioners as aforesaid that any person committed to prison for Trial for any offence is insane or is an idiot, it shall be lawful for such Governor, if he shall think fit, in like manner to order that such Person shall be removed to such Lunatic Asylum as he shall appoint, unless in the meantime admitted to bail by some legal authority until the sitting of the Court at which such person should be tried or indicted according to the due course of law, and that such person shall then be remitted to the custody of the Keeper of the Gaol or other person in whose custody such person may have been, under the terms of the original committal, in order to his being indicted and tried for such offence or otherwise disposed of according to law; provided always that every such person, while so detained in such Lunatic Asylum, shall have the same liberty of seeing his friends and legal advisers at all reasonable times which he would have had in the gaol or prison from which he may have been removed.

" 6. - In all cases where it shall be given in evidence upon the trial of any person charged with any Treason, Murder, Felony, or Misdemeanor, that such person was insane at the time of the commission of such offence, and such person shall be acquitted, the Jury shall be required to find specially whether such person was insane at the time of the commission of such offence, and to declare whether such person was acquitted by them on account of such Insanity; and if they find that 
such person was insane at the time of committing such offence, the Court, before whom such trial shall be had, shall order such person to be kept in strict curstody in such Gaol or place of confinement and in such manner as, to the Court, shall seem fit until the Governor's pleasure shall be known; and it shall thereupon be lawful for the Governor to give such order for the safe custody of such person during his pleasure in such place and in such manner as, to the Governor, shall seem fit.

“7.-If it shall appear to any two legally-qualified Medical Practitioners present at any examination of any Person in custody that such Person is not insane or a dangerous idiot, and that such person may be suffered to go at large with safety, it shall be lawful for such Practitioners, and they are hereby required to give a Certificate to that effect, signed by them, to the Visiting Justice, or in his absence, to the Keeper of the Gaol or House of Correction in which such person is in custody, who is hereby required to transmit the same forthwith to the Governor for the time being, who shall order the liberation of such person from custody, unless he shall be detained therein for some other cause by due process of law.

“ 8. - It shall be lawful for the Governor to nominate and appoint some fit person or persons to be Visitor or Visitors of such Lunatic Asylums within the Colony ; and the said Visitor or Visitors to remove and displace, and to appoint another or others in his or their stead : the persons so appointed shall visit such Asylums and make Reports thereon at such times and in such manner as the Governor shall from time to time direct and appoint.

"9.-And whereas, it is also desirable to provide for the care and maintenance of Persons who are insane, but not dangerously so : Be it enacted that it shall be lawful for the Governor, on the application of one or more of the relatives or guardians or friends of any insane person (which application shall be sanctioned in writing by one of the Judges of the Supreme Court), and on receiving the certificate of two legally-qualified Medical Practitioners that they have examined and found such person to be of unsound mind, to direct and order, if he think it proper so to do, that such Person be received in such Lunatic Asylum as he, the said Governor, shall appoint.

"10. - When any insane Person shall be committed to any Gaol or Hospital as aforesaid for the purpose of being received into such Lunatic Asylum as the said Governor may appoint, the removal to and from, and maintenance in the said Asylum of such Insane Person shall, until further provision be made, be at the expense of the Colony.

" 11.-Provided always, and be it further enacted, that it shall be lawful for the Superintendent of any such Asylum, in all cases where any Lunatic or Idiot shall be possessed of sufficient means to defray the expense of his or her maintenance in any such Asylum, to agree with any relative, guardian, or friend of any such Lunatic or Idiot for his or her maintenance whilst detained therein.

voL. XVIII. 
"12.-No action shall be bronght against any person or persons on account of any act, matter, or thing done or to be done, or commanded by such person or persons in carrying the provisions of this ordinance into effect, unless such action be commenced within three calendar months after the cause of action or complaint shall have arisen; and in any such action the general issue may be pleaded, and the special matter given in evidence.

" 13. - For the purposes of this ordinance, no person shall be deemed a legally-qualified Medical Practitioner unless such Person shall have proved to the satisfaction of two Justices of the Peace that he is a Doctor or Bachelor of Medicine of some University, or a Physician or Surgeon, licensed or admitted as such by some College of Physicians or Burgeons in Great Britain or Ireland, or a Member of the Company of Apothecaries of London, or who is, or has been, a Medical Officer duly appointed and confirmed of Her Majesty's Bea or Land Service.

c 14.-Provided that nothing herein contained shall be construed to prevent a writ de lunatico inquirendo from being sued out of the Supreme Court by any person or persons having a lawful right to do so for the purpose of having the fact of the insanity or idiotcy of any person not dangerously insane or idiotic tried by due course of law.

"15. - For the purposes of this ordinance, the word 'Governor' shall be taken to include the 'Lieutenant-Governor,' or the Officer administering the Government of the Colony for the time being. (Bigned) Grorar Gres, Lieutenant-Governor and Commander-in-Chief.

Passed the Legislative Council

this 18th day of November, 1846,

(Signed)

\section{J. Contres,}

Clerk of Councils."

\section{II.-Lunatics Ordinance Amendment Act, 21 and 22} Vict., No. 61.

"An Act to amend an ordinance to make provision for the safe custody of, and prevention of offences by, persons dangerously insane, and for the care and maintenance of persons of unsound mind : passed 19th August, 1858.

“Title.

Analysis.

"Preamble.

“1. - Resident Magi strate or two Justices may, on being satisfied by information on oath, apprehend a person believed to be suffering from mental derangement.

" 2.-Resident Magistrate or two Justices, being satisfied by declaration on oath of Medical Practitioners, may forthwith commit to some place of safe custody. 
" 3.-Resident Magistrate or two Justices may on being satisfied by declaration on oath of Medical Practitioners, order person of unsound mind to be received into some Public Lunatic Asylum or Hospital.

"4.-Person committed may be handed over to the custody of his friends on their entering into surety that he shall receive proper treatment and keep the peace.

"5.-Superintendents may visit and inspect Lanatic Asylums.

"6.-Legally-qualified Medical Practitioners defined.

“ 7.-Bection IX of Ordinance XXI of Bession VII repealed.

" 8.-Bhort Title.

"Whereas, by an Ordinance enacted by the Governor of New Zealand, with the advice and consent of the Legislative Council thereof, Session VII, No. 21, entituled 'An Ordinance to make provision for the safe custody of, and prevention of offences by, persons dangerously insane, and for the care and maintenance of persons of unsound mind,' it is enacted that dangerous lunatics and persons of unsound mind may be apprehended and kept in custody in the manner therein provided : And whereas it is expedient that further provision be made for the apprehension and safe custody of persons suffering under mental derangement by whatever cause produced, and for the prevention of mischief of any kind whatever at the hands of persons liable at various and uncertain times or periods to attacks of mental alienation, whether temporary or permanent :

"Be it therefore enacted by the General Assembly of New Zealand in Parliament assembled, and by the authority of the same, as follows:-

" 1.-It shall be lawful for any Resident Magistrate, or any two Justices of the Peace, on being satisfied by information npon oath that there is reasonable ground to believe that any person is suffering from mental derangement, either permanently or temporarily as aforesaid, which is likely to endanger the safety of any person whomsoever, or to result in any injury to property, to issue by warrant under his hand and seal, or their hands and seals as the case may be, an order for the apprehension of the person so believed to be suffering from such mental derangement as aforesaid, and for his detention in a place of safe custody in such convenient manner as the said Magistrate or Justices shall direct; and such person so apprehended shall forthwith be brought before the same, or other Resident Magistrate or Justices of the Peace, at some convenient place to be named in the warrant of apprehension, to be further dealt with as hereinafter provided.

" 2.-The Resident Magistrate or Justices before whom such person shall be brought as aforesaid, shall, without any unnecessary delay, direct two or more legally-qualified Medical Practitioners forthwith to examine the person so apprehended; and if, upon view and examination of the person so detained in custody, the said Medical Practitioners shall declare upon oath that, in their opinion, the person 
so detained in custody is at that time, or is likely shortly to become, dangerous to himself or others, or is in any way disposed to violence, it shall be lawful for such Resident Magistrate or Justices of the Peace by warrant under his hand and seal, or their hands and seals as the case may be, to commit such person to some Public Lnnatic Asylum, or in the event of none such being available, to some Public Hospital, Gaol, or other place of safe custody, there to be kept in safe custody until such person shall be discharged by order of a Resident Magistrate or any two Justices of the Peace; and if any Medical Practitioner, not being in full pay in Her Majesty's land or sea forces, shall refuse to visit, examine and report upon the condition of any lunatic as above provided, he shall be liable to a penalty of not more than $\$ 50$ for each offence, to be recovered in a summary way.

" 3.-And whereas it is also desirable to provide for the care and maintenance of persons who are of unsound mind, who may not have shown a disposition to violence : Be it enacted that it shall be lawful for any Resident Magistrate, or any two Justices of the Peace, on application of one or more of the relatives or friends of any person of unsound mind, and on receiving a declaration on oath from two or more legally-qualified Medical Practitioners that they have examined and found such person to be of unsound mind, to direct and order, if he or they think proper so to do, that such person be received in such Public Lunatic Asylum or Hospital as such Resident Magistrate or Justices may appoint. Provided always that no such direction or order shall be acted upon unless and until the same shall have been endorsed with the signature of a Judge of the Supreme Court, or the Superintendent of the Province in which such Lunatic Asylum or Hospital is situate, after a proper inquiry by him, if he shall think fit, as to the propriety of carrying out such order or direction.

"4.- Provided always that the person so committed to any Lunatic Asylum, or other place of safe custody as aforesaid, may at any time be handed over to the care of any of his relatives or friends, upon their making application to that effect, and entering into such sureties as may be deemed sufficient by any Resident Magistrate or any two Justices of the Peace that the person so proposed to be enlarged shall receive proper treatment while in their custody, and shall keep the peace towards himself and all Her Majesty's subjects, and such sureties shall only be discharged by two Justices of the Peace.

" 5.- It shall be lawful for the Superintendent of any Province to visit and inspect any Lunatic Asylum or Hospital situated within the province of which he is Superintendent, at such times as he may deem convenient.

"6.-Every person holding a degree or diploma, or license in Medicine or Surgery from any University or College or other corporate body duly anthorised to grant the same in Great Britain or Ireland, or who is a Member of the Company of Apothecaries of London or Dublin, or who is or has been a Medical Officer in her Majesty's 
land or sea service, shall be deemed a legally-qualified Medical Practitioner for the purpuses of this Act.

"7.-Section IX of the said recited Ordinance, No. XXI of Session VII of the Legislative Council, and all other provisions contained in the said Ordinance, which are repugnant to any provisions of this Act, are hereby repealed.

" 8. -The short title of this Act shall be 'The Lunatics' Ordinunce Amendment Act, 1858." 18

It is evident that the main object of both the Acts just recited is protection of the public from the nuisance of criminal or dangerous lunacy, by providing for the custody of certain pests of society. This is always the case in young colonies. Attention is drawn to the Insane, in the first place by reason of the necessity that exists to provide for the elimination from society of wandering Lunatics, who are not only non-productive citizens, but who threaten the public safety or public decorum. Even in the case of those insane colonists, who cannot be pronounced dangerous either to themselves or others, the object of all early legislation is safe custody, not curative nor restorative treatment. Even at the present day, in the Lunatic Hospital of the Government Metropolis of New Zealand, Wellington,no attempt apparently is made at curative treatment ! Thus we find in the "Minutes of Evidence" appended to the "Report of the Joint Committee on Lunatic Asylums" of 1871, the following statements by the Physicians to the said Asylum near the City of Wellington. Dr. Johnston was asked " Did you use any curative means when you were there P" "No," he replied, "I had no opportunity. . . . . When I visited the Karori Asylum I had no moral control. I merely attended the patients professionally in the case of illness." "Had you any amusement for the patients? any curative treatment ?" "No, none." "Had the attendants any special knowledge of the treatment of Lunatics?" "No. I believe those who had charge of them were uneducated, and not at all capable to administer

13 The Agent-General for New Zealand in Great Britain (then John Morrison, Esq., of London), informed me by letter, of date January, 1872, that "The 'Lunatics' Act, 1868,' repeals all Acts existing at that time relating to Lunacy, and is the only one now in force in New Zealand." He adds that " the copies of New Zealand Acts kept in this office are all bound; and are never allowed to leave the office; but at the same time anybody is at liberty to see them, and if necessary can take copies." I have not, however, had any opportunity of perusing the Statute of 1868, so that I am unaware of the extent to which the Acts of 1846 and 1858 have been modified by subsequent legislation. 
curative treatment." "Are you aware that any patient has been discharged as cured from the Wellington Asylum ?" "I believe so ; but I do not know of my own knowledge. I think they have been left very much alone, and sometimes Nature has re-asserted itself!" Dr. France was asked - "Do the patients ever get out? Leave the asylum?" "No; there is no arrangement for their going away." "Do they never leave the asylum ?" "No." "Do you allow the patients out of control occasionally?" "We have no means of doing so." "How do you mean, no means?" "No means of letting them out except as cured." "If their friends gave a guarantee?" "They have no friends; they are paupers." "Are there any out with friends at present P" "No; none are out. We cannot send them out to get a living or employment !"

Both the acts of 1846 and 1858 contain terms [such as " keeper"] which are equally objectionable and obsolete. The existence of the asylum-physician is ignored in certification [clause 4, Act 1846]; a circumstance due, no doubt, to there being as yet no resident physician-superintendents in any of the asylums of New Zealand. The power of the governor of the colony is much too great or exclusive : and he is burdened with a kind and amount of work from which he should be free [Clause 9, Act 1846]. All necessary powers - of granting warrant for admission into asylums -should be vested in the local justices of the peace, judges, or other legal officials. Troo medical certificates are unnecessary ${ }^{14}$ - though unquestionably they are an advantage, where obtainable. But it is not always possible or easy to procure even one; and the absence of a second may prove a serious obstacle to prompt or timely transfer to, or admission into, a proper lunatic hospital. Clause 13 of Act 1846, is too exclusive in its definition of qualified medical practitioners. The category should be made to include physicians trained in the medical schools of Continental Europoespecially of Germany, France, and Italy; as well as of the leading British Colonies and the States of the American Union. All degrees or diplomas - of an authentic and satisfactory character-should be duly recognized and accepted

14 We have the assurance of one of the most experienced alienists of the United Stateo-Dr. Kirkbride, of the Pennsylvania Hospital for the Insane, at Philadelphia-that one certificate- "in the simplest form, without evidences"-is sufficient for all practical purposes. [Vide Dr. Robertson's "Visit to American Asylums :" "Journal of Mental Science" for April, 1869, p 73.] 
as titles to practice and certify. Obligatory certification [Clause 2, Act 1858] is a glaring injustico-especially in a country where actions for damages are much more common than at home. This legal compulsion to certify certainly, however, defeats its own end. I found among the medical practitioners of New Zealand great ignorance of the phenomena and treatment of insanity ; a consequent timidity in testifying to its presence; and a resultant impossibility of obtaining necessary legal proceedings in manifest cases of lunacy. ${ }^{16}$ Medical men, if compelled to certify, prefer not to commit themselves to the possible results of pronouncing a verdict of insanity. There is the same dubiety about moral insanity-including, especially, that common form of it known as Dipsomania-in our colonies as at home; and no wonder, so long as our colonial cousins are guided by the remarks of the lawyers and the press in such public trials as thosein England-of Watson and Edmunds, in January, 1872. In clause 3, of the same Act, the resident magistrate or justices have powers of too arbitrary a kind; while the formalities connected with the admission of patients are unnecessarily and mischievously complex. ${ }^{16}$

So far as I am aware, there are yet ne asylums for the insane in the provinces of Hawkes Bay, Taranaki, Marlborough, or Southland; while those of Nelson and Wellington are notoriously defective. Hence the necessity-that still exists-of committing all classes of the insane-oven those who are harmless, and belong to the educated classesto public gaols, houses of correction, or general hospitals or infirmaries ; either for permanent custody, or as a temporary measure prior to transfer to some special lunatic hospital.

16 In one case-where certificates from local practitioners could not be procured, my assistance was solicited, along with that of the surgeon of a newly-arrived emigrant ship, in order to the establishment before a court of law of an obvious case of lunacy - of the moral insanity type.

16 Compared with the similar formalities in Britain, the procedure necessary in certain, at least, of the States of the American Union is a model of simplicity. One medical certificate; an application by one relative; and an obligation by him for payment of board-are the only documents required. The warrant of no legal authority of any kind is exacted!. And these aimple forms answer, we are assured, quite as well as the confusingly complex ones in ase in our own country. Patients may also, however, be committed by order of a court, judge, justice, magistrate, or other legal or public authority.

${ }_{17}$ Precisely similar was the state of matters at one time in New Bouth Wales. The Rev. Dr. Lang, of Sydney, in his account of that colony [Vol. II, appendix, p. 569], gives among diseases treated at the Sydney Infirmary and Dispensary during the jear 1850, four cases of manis in the Infirmary, and three in the Dispeneary. 
The effect of the association of lunatics with criminals in the public gaols of New Zealand has been freely commented on by various of the medical or other officers of these institutions. Thus Mr. Stoddart, keeper of the Public Prison of Dunedin, and Dr. Hulme, the Provincial Surgeon of Otago, long ago directed public attention to the difficulty of managing criminals when associated in the same building with lunatics, and the injustice of housing together in a general hospital patients afflicted with ordinary surgical and medical ailments on the one hand, and with mental aberration on the other. In the statistics of the Dunedin Hospital for 1861-2, drawn up by Dr. Hulme, the Provincial Surgeon of Otago, it is recorded that six lunatics were resident in it at the beginning of the year; while 12 were admitted during its currency. In his report for 1862-3, 12 were resident at the beginning of the year, while 24 were admitted during its currency. Dr. Hulme remarks, " among the lunatics are many cases of old incurable inmates; the number discharged, cured and benefited, is above the average; and one death only is below the average in asylums in Europe." The gaoler of Dunedin (Stoddart), in his Report for 1863, observes, "The confinement of Junatics here is very objectionable and dangerous. Latterly, through the crowded state of the gaol, I was obliged to put them in the same cells with criminals. The disturbance created by some of them at night renders it impossible for the officers to detect any attempt to escape made by the convicts."18 Nevertheless the Report of the Governor of the same Dunedin Gaol, for the year ending March, 1869, says that six lunatics had been admitted during the said year. In the "Minutes of Evidence" of 1871, in reference to the province and city of Wellington, Dr. Johnston was asked-" "You say there are three (lunatics) in the gaol, and two in the hospital. Why were they admitted ?" "Because there was no accommodation and no room for them elsewhere. ...... I have often received complaints from the warder of the gaol that the noise made by lunatics there is sufficient to keep the hardlabour prisoners awake all night, and give them great reason for making excuses that they were not fit to go out to work.

18 An incident, that went the round of the Otago newspapers in 1863, headed "Jenkins again," brought out the difficulties the gaol authorities had to contend with in the management together of lunatics and criminals. A quotation thereanent from the “Otago Daily Times," of September 28th, 1863, is given in my paper on "Insanity in Brittsh Emigranta," p. 226. 
Keeping lunatics there was subversive of all discipline." Dr. McGauran, Provincial Surgeon of Auckland, in his Report on the Provincial Lunatic Asylum, in January, 1858, tells us that in addition to its population " seven other lunatics have been under my care in the Hospital, Stockade, and Gaol." In his next year's Report, 1859, "three had been transferred from the Hospital and Gaol, where they had been under treatment during 1857."19

There ought to be some legislative enactment, punishing, if it be possible, all who are accessory to the sending or receiving from the home country of persons labouring under any form or stage of insanity, who are not provided with adequate funds for their independent maintenance. These penal enactments should be made sufficiently public both in Britain and in the Colony itself. Every now and then incidents such as the following are recorded in the Colonial newspapers :- "Among the female passengers of the emigrant ship, 'Peter Denny,' which arrived at Port Chalmers from Glasgow, on the 12th ulto., there was an unfortunate lunatic. She appears to have been surreptitiously placed on board by a medical gentleman (?), who thought fit to take advantage of the absence of any penal enactment in this Colony which could meet such a case. As this description of fraud has of late become common, our Legislature will probably. lose no time in providing against it for the future.",20 This transshipment or importation of lunatics or imbeciles from Britain - the immigration of cases of moral insanity, or persons tainted with dipsomania - of ne'er-do-wells, who swell the ranks of idlers, gamblers, swindlers, frequenters of low society-undoubtedly adds materially to the insane population of New Zealand and other British colonies. Sometimes imbeciles and lunatics are sent abroad with a knowledge, on the part of the relatives or friends, of the mental want or perversion, simply in order to rid themselves of a family encumbrance and a domestic nuisance. Sometimes, on the other hand, there may be genuine ignorance of the real state of mind of the unfortunate exile-coupled with a belief that casting the idler or the apathetic youth on his own resources in an energetic young community, where he and his peculiarities are unknown, will prove his salvation from

10 In the Hospital and Grol of Wangamui, in the Province of Wellington, there is similar provision for the insane, according to Major Blewitt, of the 65th Regt.

.20. “Otago Daily Times," June 9th, 1869. 
a life of uselessness to himself or others, by giving him the opportunity of "turning over a new leaf" in his life." In either case, however, measures should be adopted by the Colonial authorities-so far as possible-to meet and counteract the evils arising from the immigration of the insane or imbecile. Such measures should include, for instance-

(1.) The more thorough inspection of the passengers of emigrant or other vessels sailing from British to New Zealand ports.

(2.) An equally careful inspection of such passengers on their arrival out. The captain of the vessel, its doctor, matron, officers, and crew, as well as the various grades of passengers, could throw important light on the true nature of the peculiarities of many troublesome shipmates.

(3.) The immediate return to Britain of immigrants found, on arrival out, to be insane or imbecile, and unprovided with funds for their independent maintenance. Such a step, however costly, would ultimately lead to great saving to the various Provincial exchequers.

There is evidence in both the New Zealand Lunacy Acts of 1846 and 1858 that they have been based on the model of English statutes. There could, however, be no greater mistake than for any of our colonies to copy English practices or adopt English views regarding the State management of the insane. Our Lunacy Laws are numerous, complex, and elaborate to a confusing degree. Our legal criteria of insanity are the grossest scientific absurdities, and involve the gravest practical fallacies or errors. We occasionally hang our insane, and refuse the ordinary rites of burial to our suicides. ${ }^{2}$ There could, for instance, be no grosser perversion of justice than the recent condemnation, by an incompetent jury, ${ }^{23}$ of the Rev. John Selby Watson and Miss Christina Edmunds (both in January, 1872), in oppo-

21 Vide also what I have said on this sabject in a paper on "Insanity in British Emigrants of the Middle and Upper Ranks," in the "Edinburgh Medical Journal" for September, 1869, p. 217.

2. A celebrated Australian case, comparable anfortunately to some of our own, is that of Miss Loftus, quoted in my "Suggestions for the Supervision of the Insane in our Colonies," p.485, foot note. Compare it e. g. with the newspaper accounts of an English case of felo-de-se that occurred in the Isle of Wight so lately as January, 1872.

23 The incompetency of ordinary juries to deal with questions involving the determination of the existence or non-eristence of the numerous and frequently puzzling forms of mental disease, renders it highly desirable that, if such questions are to be brought before such juries at all, the jurymen should be aesisted in their judgment by competent medical experts. 
sition to the strongest and highest medical testimony in favour of the insanity of both. Whatever may be said by lawyers and journalists, the nature of the crime itself is, in such cases, one of the most convincing proofs of insanity to the experienced alienist. The untenable legal dogma of a knowledge of right and wrong, as a test of insanity, was laid down by the presiding judge (Baron Martin) in the Edmunds' case, where the evidence of hereditary insanity was overwhelming. Those who, in this country, are charged by Government with the administration of lunacy matters, whether these authorities are medical or legal, are too frequently doctrinaires, who hold impracticable, speculative views, which, as mischievous hobbies, they ride usque ad nauseam. Our public opinion at present errs egregiously in the direction of granting too great license and indulgence to the insane; the results whereof include, inter alia, a succession of homicides and suicides, the record of which gives a permanently sensational character to our daily press. Our system of Barracking the insane and imbecile in enormous central establishments is now universally condemned by competent authorities. The hospital plan of treatment itself is shown to be radically mischievous. And in short, in certain respects at least, lunacy reform is not less wanted in England than in our colonies! So far from our present lunacy system tending to prevent, repress, or minimise lunacy, it has a precisely contrary effect; and the time approaches when the public will object to expend unlimited funds on the unlimited construction of lunatic asylums, which, however large or numerous, are found powerless to stem the ever-rising tide of lunacy. If this be the case, England is not in a position to offer models for her colonies to imitate. Rather should it be her mission to hold out warnings for her danghters-cautions to avoid the errors which she has, over and over again, obstinately committed. In framing future statutory provision for the management of the colonial insane, the Lunacy Laws of certain of the American United States, and not those of Britain, should be adopted as a model by New Zealand. Even Norway (as I have elsewhere shown) is in advance of England as regards the brevity and simplicity of its Lunacy Laws." Over-legislation will be the inevitable result of taking, as a model for a

* Vide "Insanity and Lunatic Asylums in Norway :" Reprint from "Quarterly Journal of Psychological Medicine," April, 1858, pp. 8, 41 and 44. The simplicity of the admisaion-forms into asylums is commented on ut p. 20. 
colony, the Lunacy Statutes of either England, Scotland, or Ireland. ${ }^{25}$

Its "Report on Lunatic Asylums" of 1871 shows conclusively the importance to the New Zealand Government of the presence in the Colony of some officer capable of advising it on all the intricate subjects or questions connected with the erection and administration of Lunatic Asylums in the different Provinces, and on dealing with those forms of Insanity that puzzle and perplex local medical or legal authorities. The report in question contains ample evidence of the necessity at present existing for reform in Lunacy affairs in New Zealand; but, though it embodies the suggestions of all the principal authorities in the colony connected with the management of the various local Asylums, few, if any, of these suggestions are of any real value-proceeding as they do from men confessedly ignorant, more or less, of the difficult specialty on which they do not hesitate nevertheless to express confident opinions. There is only one way of securing to the colony the services of competent Lunacy Experts, viz., by the offer of handsome inducements to men trained in Britain to emigrate to the Antipodes. But at present it seems hopeless to expect the New Zealand Government or Public to grant the necessary funds. Colonial ideas of the salaries sufficient to secure at and from home the services of first-class experts are of the most amusing character-amusing for the gross ignorance or the arrant conceit they display. Only the other day, for instance, the Otago Provincial Government was about to instruct its home agent to look out for a firstclass Inspector of Schools at the munificent salary of $\$ 400$ a year! The Otago Government would have been fortunate had it succeeded in obtaining a good sixth-class clerk from home for such a pittance. The same Government seems to have been seized with that mania for retrenchment that periodically affects all Governments. ${ }^{26}$ After a fifteen years' service it has reduced the salary of its Provincial Inspector of Schools (a man who has been the main instrument of

25 The well-known American alienist, Dr. Ray, in a paper on "American Legislation on Insanity," points out on the one hand the evils of overlegislation in England, and on the other the simplicity of the formalities for admission into asylumsin America.- [Vide "Journal of Mental Science" for Jannary, 1865, pp. 576 and 578. At p. 581 will be found a "Project of a General Law for determining the Legal Relations of the Insane."]

26 A telegram of 10th July, 1869, from Sydney informed us that "Government intends to reduce the expenditure of the Lunatic Asylum and Gaol Departments ;" whereas it might fitly have made a grant of at least $\$ 100,000$ to provide proper asylum accommodation for New South Wales. 
originating and putting into working order one of the best systems of education to be found in any of the British Colonies) from $£ 500$ to $£ 400$; while the emoluments of the Surveyor-General of the Province-a public officer of still older standing (who has had all the hard work of exploring as well as surveying the province from the very date of its settlement) -is rewarded by having his salary cut down from $£ 700$ to $£ 400$ ! Does it not occur to the parsimonious Government authorities of Otago to contrast the salaries they venture to offer to first-class officials with the emoluments of many classes of the general public-the majority of the members of which are greatly the inferiors of the officials in question, both in general culture and in special knowledge. For instance, merchants of all kinds-men frequently of no special culture and of no signal ability save that, often of a questionable kind, which is implied in the aptitude for accumulating money-both at home and abroad-easily make as many thousands per annum as the Otago Government offers hundreds to its highest officials. Even the assistants, confidential clerks, commercial travellers, or shopkeepers, of merchants or mercantile firms often have upwards of $£ 1,000$ a year. Again, the managers, and even the provincial agents of Bank and Insurance Companies have frequently an annual salary of $\mathfrak{E} 1,000$ or more. Indeed, the category of persons making upwards of $£ 1,000$ a year is a numerous one in the home country as in our colonies; and it embraces very different classes of men, professional and non-professional. Nor can I believe that the Government authorities of New Zealand, in determining the salaries that should be offered to persons selected at home for their special experience or ability in any sphere of usefulness, bear in mind, if they are acquainted with, the salaries giren to clerks in our own Colonial Office. As stated in the English newspapers of Nov., 1872, there are in that office three classes or grades of clerks-the first or senior having $£ 1000$ a year, rising to $£ 1200$; the second $£ 600$ to $£ 900$; and the third $£ 250$, rising by $£ 20$ a year to $£ 600$. Quite recently the well-known Metropolitan Asylum of Hanwell (London) failed to obtain such a Physician as would satisfy the requirements of the Directors, notwithstanding

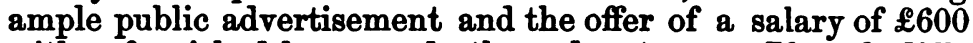
with a furnished house and other advantages. If such difficulties occur in Fngland in securing an ordinary Asylum Physician, they are much more likely to occur in a colony when it solicits from home a competent Inspector of Asylums. 
or Commissioner in Lunacy even at a salary double that which can easily be commanded by Asylum Physicians in the boune country.

In England there are, at least, five public lunacy physicians who draw upwards of $\& 1,000$ of official salary, viz. :-Three Medical Commissioners in Lunacy and two Visitors of Chancery Lunatics. There are, moreover, several physicians to public asylums, whose emoluments amount to about 21,000 -their official salary varying from $£ 400$ to $£ 800$, with, in addition house, furnished or not, coals, gas, vegetables, dairy produce, or board for self and family - in different cases. In Scotland there are, at least, four lunacy physicians, with emolaments of $£ 1,000$ a year or upwards, viz. :-Two Medical Commissioners in Lunacy, and two physicians of public asylums. There are besides several others, whose income ranges from

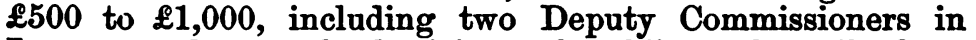
Lunacy, and several physicians of public asylums." Considering the difference in value between home and colonial salaries, in relation to the cost of living and travel, the sum of $£ 2,000^{28}$ a year for a colonial Inspectorship of asylums or Commissionership in lunacy must be regarded as both modest and moderate. ${ }^{20}$ The holder of such an office should, moreover, have a liberal superannuation allowance after a comparatively short period of active servicomuch shorter than at home-so that he may return, should he so desire, to the mother-country with a certain measure of vigour, and capacity for the enjoyment of the remainder of

27 The reader will find a table showing the emoluments of a number of medical practitioners in lunacy, at home and abroad, in my paper on "Colonial Lunacy Boards, with special reference to New Zealand," in the "Edin. Medical Journal" for March, 1872. But since that Table was published, increase- to the extent of $\$ 100$ or $\$ 150$ a year in each case-has been made to the salaries of several of the Physicians specified; while the names of several others, whose income now ranges between $£ 500$ and $\$ 1,000$ a year, fall to be added to the list.

as My public critics in Otago, including Dr. Buchanan, have misunderstood what I said, at the close of my Paper in the "Edin. Med. Journal" of March, 1872, concerning $\$ 4000$ a year as a suitable salary for a Colonial Commissioner in Lunacy. What I did say was that, if certain data were accepted as the basis of calculation, the result would give the sum in question. But I did not recommend, nor did I even or ever dream of recommending-the New Zealand Government to offer such a sum to its Inspector-General of Asylums, for this sufficient reason, that I know there is very small chance of inducing the Colonial Anthorities to give even the half of it!

"I I have the lees hesitation in remarking upon the emoluments of a Colonial Inspector of Asylums, that many of my observations apply (mutatis mutandis) also to the Physicians of the various Provincial Asylums in New Zealand. 
his life. The present holders of such offices in our colonies are generally men who have enjoyed no prominent status nor signal reputation at home-youngsters mostly who have been taken from the assistantships of English county asylums. Plenty of the medical assistants of these institutions may probably be got to accept the offer of a colonial government to surpervise its asylums; just because their prospects at home are narrow and unpromising amid the competition that exists. But the limited experience of these gentlemen is not of a kind to qualify for the occupation of so important a post as that of a commissionership in lunacy in a new country. It is certainly not a sufficient qualification for a colonial inspector of asylums that a young, unknown, untried physician should have gathered a certain kind and amount of experience in one of the numerous and common-place county asylums of England. ${ }^{20}$

It would be unprofitable, however, further to discuss at present the defects of the New Zealand Lunacy Statutes, or the errors of that Government in its arrangements for the treatment of the insane. Suffice it, for the present, to indicate the following desideranda as requiring the attention of the New Zealand Legislature :-

"1.-The consolidation and simplification of the Lunacy Statutes on some of the best American models.

"2.-The greatest practicable simplification of the forms of Admission into and Discharge from asylums.

" 8. -The supply of skilled officers of all grades to the various Provincial Asylums.

"4.-The provision of a proper Lunacy Buard for the colony.

"5.-The substitution of trial by or before Experts for ordinary trial by jury-in disputed lunacy cases.

"6.-The provision of different Classes of Asylums, including :-

"(a) Proper asylums in Provinces where at present there are none.

“(b) A central Gheel colony for the economical application of the industry of harmless imbeciles and the chronic insane.

“(c) Refornatories for habitual or insane Inebriates.

"(d) Clinical City-asylums.

“(e) Country Receiving houses; or Parochial Cottage-asylums.

"(f) Private ayjlums for the Affluent classes.

“ 7.-Collection of reliable Statistics of Insanity in the colony-as affecting both Maories and settlers."

20 The whole subject of Colonial Inunacy Commierionors will be foand discuseed in my paper on "Colonial Lunacy Boards," already quoted. 

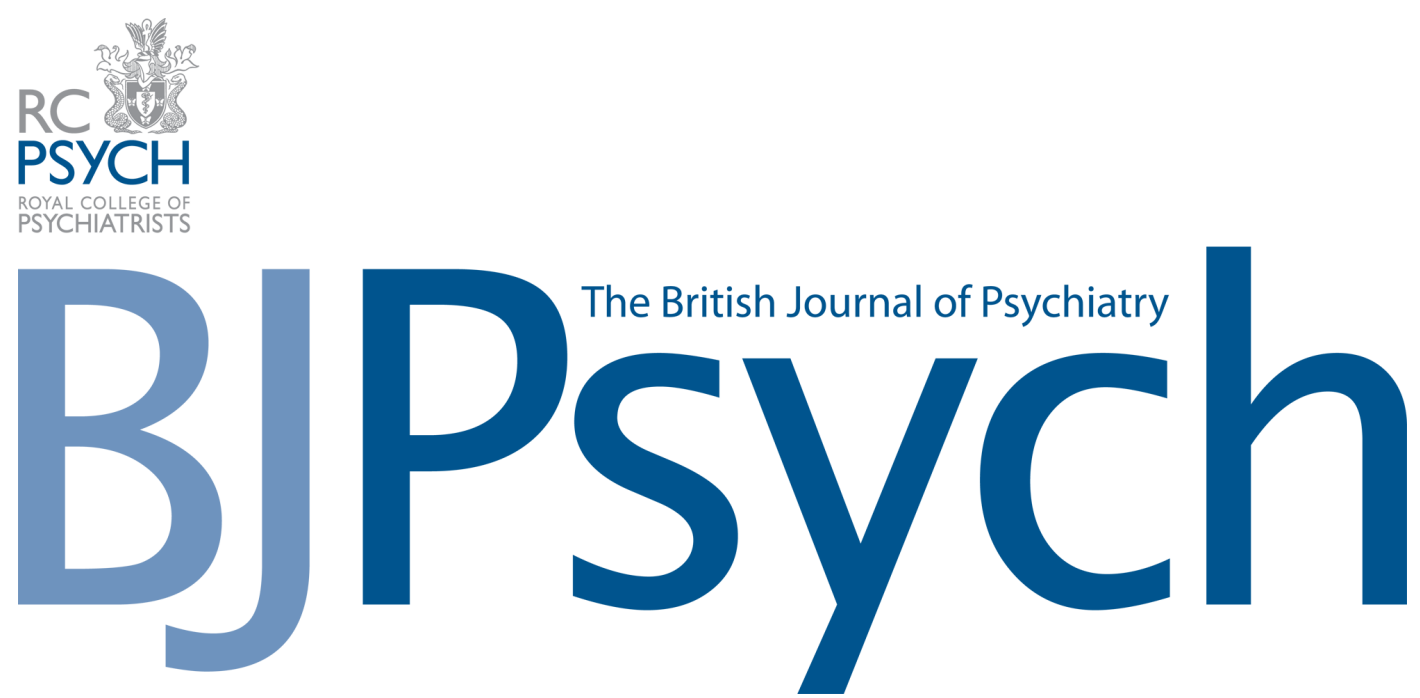

\section{Lunacy Legislation in New Zealand}

W. Lauder Lindsay

BJP 1873, 18:498-521.

Access the most recent version at DOI: 10.1192/bjp.18.84.498

\begin{tabular}{cl}
\hline References & $\begin{array}{c}\text { This article cites } 0 \text { articles, } 0 \text { of which you can access for free at: } \\
\text { http://bjp.rcpsych.org/content/18/84/498.citation\#BIBL }\end{array}$ \\
$\begin{array}{c}\text { Reprints/ } \\
\text { permissions }\end{array}$ & $\begin{array}{l}\text { To obtain reprints or permission to reproduce material from this paper, please write } \\
\text { to permissions@rcpsych.ac.uk }\end{array}$ \\
$\begin{array}{c}\text { You can respond } \\
\text { to this article at } \\
\text { Downloaded } \\
\text { from }\end{array}$ & $\begin{array}{c}\text { /letters/submit/bjprcpsych;18/84/498 } \\
\text { Published by The Royal College of Psychiatrists }\end{array}$ \\
\hline
\end{tabular}

To subscribe to The British Journal of Psychiatry go to: http://bjp.rcpsych.org/site/subscriptions/ 